慶應義塾大学学術情報リポジトリ

Keio Associated Repository of Academic resouces

\begin{tabular}{|c|l|}
\hline Title & $\begin{array}{l}\text { Effect of Preinfarction Angina Pectoris on ST-Segment Resolution After Primary Coronary } \\
\text { Angioplasty for Acute Myocardial Infarction. }\end{array}$ \\
\hline Sub Title & 急性心筋梗塞に対する経皮的冠血行再建術後のST偏位改善に及ぼす梗塞前狭心症の影響 \\
\hline Author & 高橋, 寿由樹(Takahashi, Toshiyuki) \\
\hline Publisher & 慶應医学会 \\
\hline Publication year & 2003 \\
\hline Jtitle & 慶應医学 (Journal of the Keio Medical Society). Vol.80, No.2 (2003. 6),p.24- \\
\hline JaLC DOI & \\
\hline Abstract & \\
\hline Notes & 号外 \\
\hline Genre & Journal Article \\
\hline URL & https://koara.lib.keio.ac.jp/xoonips/modules/xoonips/detail.php?koara_id=AN00069296-2003060 \\
& 2-0024 \\
\hline
\end{tabular}

慶應義塾大学学術情報リポジトリ(KOARA)に掲載されているコンテンッの著作権は、それぞれの著作者、学会または出版社/発行者に帰属し、その権利は著作権法によって 保護されています。引用にあたっては、著作権法を遵守してご利用ください。

The copyrights of content available on the KeiO Associated Repository of Academic resources (KOARA) belong to the respective authors, academic societies, or publishers/issuers, and these rights are protected by the Japanese Copyright Act. When quoting the content, please follow the Japanese copyright act. 


\section{Effect of Preinfarction Angina Pectoris on ST-Segment Resolution After Primary Coronary Angioplasty for Acute Myocardial Infarction. \\ （急性心筋梗塞に対する経皮的冠血行再建術後のST偏位改善に及ぼす梗塞前狭心症の影響）}

\section{高 橋 寿 由 樹}

\section{内容の要旨}

\section{1. 緒言}

急性心筋梗塞の再眯通療法により責任冠動脈の良好な血流（TIMI 分類 3 度 ; 末梢まで遅延なく造影される血流）が得られても、必ず しも心筋組織レベルの再灌流が十分に得られるとは限らず、その主 因として微小循環障害が想定される。急性心筋梗塞発症前にしばし ば狭心痛を認めることがあり、この梗塞前狭心症の存在は梗塞後左 室機能㧍よび予後に良好な影響を及浔すことが過去に報告されてい る。しかし、梗塞前狭心症の微小循環障害に及ほす影響に関しては 不明であった。本研究では心筋組織再灌流の指標としてST偏位改善 率を用い、梗塞前狭心症と微小循環障害との関連を明らかにするこ とを目的とした。

2. 方法

初回急性心筋梗塞にて入院し、発症12時間以内に経皮的冠動脈形 成術（PTCA）によりTIMI-3血流が得られた連続96例を対象とした。 非ST上昇型梗塞、PTCA 前にすでにTIMI-3血流が回復していた例、 脚ブロック例は除外した。PTCA前と再疎通 1 時間後の心電図12誘導 におけるST上昇の合計を比較し、改善率 $(\% \Delta \Sigma \mathrm{ST})$ を計測した。 ST改善良好群 $(\% \Delta \Sigma \mathrm{ST} \geqq 50)$ と不良群 $(\% \Delta \Sigma \mathrm{ST}<50)$ との 2 群に 分け、梗塞前狭心症の有無を含めた患者背景因子、冠動脈造影所見、 最大C反応性蛋白 (CRP) 值、院内合併症、左室造影所見などを比較 検討した。

3. 結果

患者平均年齢は $60 \pm 12$ 歳。96例中 41 例が発症前 1 週間以内に梗塞

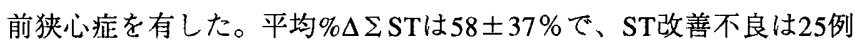
に認められた。単変量解析に扔いてST改善不良は梗塞前狭心症の欠 如 $(\mathrm{p}=0.007)$ 、前壁梗塞 $(\mathrm{p}=0.002)$ 、入院時Killip分類 $>1 \quad(\mathrm{p}=$ 0.005) と関連した。ST改善不良群では良好群と比べ、最大CRP值は 高値で、かつポンプ不全、心室頻拍・心室細動、左室瘤が高率に見 られた。発症 6 ケ月後の左室造影ではST改善不良群において左室駆 出率はより低值で、拡張末期容積はより大であった。多変量解析の 結果、梗塞前狭心症の欠如（相対危険度7.3、 $\mathrm{p}=0.002 ）$ および前壁 梗塞（相対危険度9.1、 $\mathrm{p}=0.006 ）$ がST改善不良の独立規定因子であ つた。梗塞前狭心症を有した群ではなかった群に比べ、\% $\%$ STは

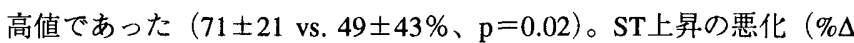
$\Sigma \mathrm{ST}<0$ ）は梗塞前狭心症を有した群では認められなかったのに対 し、梗塞前狭心症がなかった群では $13 \%$ に認められた。

4. 考察

本研究において梗塞前狭心症が心筋梗塞後の微小循環障害に対し て保護的な影響をもたらすことが示唆された。その機序として虚血 プレコンディショニングによる梗塞サイズの縮小効果に加え、梗塞 前狭心症が再灌流障害に対して抑制的に作用した可能性が考えられ た。

5 . 結論

急性期PTCAによりTIMI-3血流が得られた初回急性心筋梗塞におい て、梗塞前狭心症の存在は再灌流後のST上昇改善と関連した。

\section{論文審查の要旨}

急性心筋梗塞において再柾通療法により責任冠動脈の血行が回復 したとしても、心䇟組織再灌流が十分に得られない場合がある。こ れはno reflow現象として知られ、微小循環障害が主因である。梗塞 前狭心症の存在が梗塞後左心機能や予後に良好な影響を及ほすこと が報告されているが、本研究は梗塞前狭心症が微小循環障害にも好 影響を及はすとの仮説を立証することを目的とした。初回急性心筋 梗塞にて入院し、経皮的冠動脈形成術により TIMI分類 3 度の良好な 血流が得られた連続96例を対象とした。ST上昇を微小循環障害の指 標として用い、入院後のST偏位改善率 $(\% \Delta \Sigma \mathrm{ST})$ に上りST改善良 好群 $(\% \Delta \Sigma \mathrm{ST} \geqq 50)$ と不良群（\% $\Delta \Sigma \mathrm{ST}<50 ）$ との 2 群に分けた。 患者背景因子では、ST改善良好群に比べ不良群において梗塞前狭心 症の欠如、前壁梗塞、入院時Killip分類 $>1$ が多く認められた。ST改 善不良群では梗塞サイズがより大きく、ポンプ不全、致死性不整脈、 左室瘤などの合併症がより高率に見られ、慢性期左心機能はより低 下した。多変量解析の結果、梗塞前狭心症の欠如および前壁梗塞が ST改善不良の有意な規定因子であった。梗塞前狭心症を有した群で は無かった群に比べ、\% $\Delta \Sigma$ STは高值であった。さらに経過中のST 上昇の悪化は梗塞前狭心症が無かった群のみに認められた。これら の結果より、梗塞前狭心症が心筋梗塞後の微小循環障害に対して保 護的な影響をもたらすことが示された。

審査では、まず、ST上昇の総和により心筋虚血の重症度を評価し ているが、ST低下の総和も含めて計測した方が良いのではないかと いう指摘があった。ST低下は、ST上昇の鏡像变化を捉えている可能 性があることからSTが上昇した誘導のみで計測したと回答された。 この方法が簡便かつ有用な指標であるという欧米での報告があると された。実際に本指標が心筋組織灌流を反映することは証明されて いるかという質問に対し、心筋コントラストエコーなどを用いた他 の指標と比較してもよく相関することが示されていると回答された。 また、梗塞前狭心症の心筋保護効果の主な機序として虚血プレコン ディショニングによる虚血耐性の獲得が想定されるが、これには早 期に生じるものと種々の遺伝子、蛋白発現と関連し遅れて生じるも のとがあり、梗塞前狭心症の時間的考察、すなわち、狭心症の発症 時期、頻度などの質的評価がなされるべきではないかという指摘が あった。また、側副血行路の程度や発症前の服用薬などに相違はな かったかと問われ、梗塞前狭心症を有した群と無かった群との間で 差を認めなかったとされた。TIMI分類とno reflow現象との関連性に ついて説明を求められ、TIMI分類 2 度の血流しか得られなかった例 のほほ100\%でno reflow現象が生じていることが報告されていて、研 究対象をTIMI分類 3 度の血流が得られた症例に限定したとされた。

以上のように、本研究は今後さらに検討すべき課題を残している が、梗塞前狭心症と再疎通療法後の微小循環障害との関連性につい て明らかにした点は臨床的に有意義であり、虚血・再灌流障害の病 態を把握する上で示唆に富む研究であると評価された。

論文審査担当者 主査 内科学 小川 聡 外科学 四津 良平 臨床麻酔学 武田 純三 生理学 金子章道医化学 末松誠

学力確認担当者: 北島 政樹、四津 良平 審查委員長：四津 良平

試問日：平成15年 1 月20日 